\title{
The effect of clofazimine on the plaque-forming cell response
}

\author{
ANA VALDES-PORTELA, ${ }^{*}$ A M VAZQUEZ† \\ \& C M FINLAY* \\ * Department of Microbiology, 'Pedro Kouri' Tropical Medicine \\ Institute, Avenida 15 y calle 200 Siboney, Ciudad Habana, Cuba; \\ $\dagger$ Immunology Laboratory, National Center for Scientific Research
}

Accepted for publication 12 May 1983

Summary The plaque-forming cell (PFC) technique was used to assay the effect of
clofazimine, an antileprotic drug, on the immune system. Inbred mice were
force-fed the drug for different periods of time at concentrations of 1 and $10 \mathrm{mg} / \mathrm{kg}$
of body weight per day. After 14 and 21 days of treatment, a significant increase in
PFC response was observed. It is concluded that clofazimine exerts an effect on
the early events involved in the antibody-forming cell response.

\section{Introduction}

The treatment of leprosy has been confronted by serious problems. The early hope that the sulphone drug series would be all-sufficient for leprosy has not been fulfilled.' At present, various drugs are used in conjunction with the sulphones in the treatment of the disease. To achieve improved therapeutic methods, the mode of action of the drugs should be understood. For this purpose, our laboratories have been engaged in studying the mechanism of clofazimine, an antileprotic drug, at the cell level. Recent studies reveal that this drug exerts its action on the macrophage lysosomal apparatus by increasing de novo synthesis of lysosomal enzymes and the phagocytic capacity. ${ }^{2,3}$

Macrophage-lymphocyte interaction is a central event in the initiation and regulation of the immune response to both soluble protein and particulate antigen through antigen handling, an important event in the generation of a macrophage-associated antigenicity for T-cell recognition of antigen. ${ }^{4}$ It is now clear, for at least some antigens, that interaction of 3 cell types is required in T-dependent antibody formation systems: thymus-derived lymphocytes (T-cells),

Correspondence: Ana Valdes-Portela, 'Pedro Kourí' Tropical Medicine Institute, Avenida 15 y calle 200 Siboney, Ciudad Habana, Cuba. 
bone-marrow-derived lymphocytes (B-cells) and the macrophage. ${ }^{5-7}$ Since the macrophage participates in the immune response and clofazimine exerts its action on the macrophage, it could be assumed that the drug would have an effect, either directly or indirectly, on the lymphoid system. This study was undertaken to evaluate the effect produced by clofazimine on the functional capacity of the cell population involved in the early events of cellular cooperation.

\section{Materials and methods}

\section{MICE}

Female mice of the inbred stain, IOR/Hab, 8 weeks of age and weighing between 20 and $25 \mathrm{~g}$, were used. This strain, developed in the animal colony of the Oncology and Radiobiology Hospital in Cuba, is in the process of being recognized internationally (personal communication, Mouse Newsletter). All mice were obtained through the courtesy of Licenciado Raul Castillo.

\section{EXPERIMENTAL DESIGN}

Two groups of mice were fed by gavage during different time periods with two different concentrations of clofazimine dissolved in $0.3 \mathrm{ml}$ of sunflower oil. The doses used were $1 \mathrm{mg} / \mathrm{kg}$ of body weight per day and $10 \mathrm{mg} / \mathrm{kg}$ of body weight per day. Two control groups were used, one receiving only $0.3 \mathrm{ml}$ of sunflower oil and the other group receiving no treatment at all. Mice also received mouse pellet food and water ad libitum.

\section{PRIMING WITH HETEROLOGOUS ERYTHROCYTES}

Sheep red blood cells (SR BC) were obtained from a single animal assigned to this work at the animal colony of the National Center for Scientific Research. One week prior to use, blood was collected and stored in Alsever's solution. When required, the cells were washed 3 times in saline and finally re-suspended to an appropriate volume for injection and for use in the PFC assay. Four days prior to sacrifice, mice were immunized intraperitoneally with $0.5 \mathrm{ml}$ of a $1 \%$ solution of SRBC.

\section{PREPARATION OF CELL SUSPENSIONS}

Mice were killed by medular elongation and the spleen removed taking care to eliminate all adhering fat. The spleen was disrupted and strained through nylon and steel mesh. The cellular suspension obtained was washed once in Parker-Tris$\mathrm{HCl}$ medium $(0 \cdot 2 \mathrm{M}, \mathrm{pH} 7 \cdot 2)$. The cell counts were done in a $2 \%$ solution of crystal violet in acetic acid. Instead of counting the total number of spleen cells, 
only small mononuclear cells, easily recognizable in the crystal violet solution, by their round nucleus and scarce cytoplasm, were counted. This modification was used to adjust cell concentrations to $2 \times 10^{6} \mathrm{cells} / \mathrm{ml}$.

\section{PLAQUE-FORMING CELL ASSAY}

Direct PFC were detected by the method of Cunningham \& Szenberg. ${ }^{8}$ Briefly, to a $1 \mathrm{ml}$ spleen cell suspension, $0 \cdot 1 \mathrm{ml}$ of a $26 \%$ solution of SRBC, $0 \cdot 1 \mathrm{ml}$ of cold medium and $0 \cdot 1 \mathrm{ml}$ of fresh guinea-pig serum as complement source, were added. $0.1 \mathrm{ml}$ of this suspension was seeded into Cunningham incubation chambers, and the residual space filled with a chaser of target cells in medium. The chambers were sealed with paraffin and incubated at $37^{\circ} \mathrm{C}$ for $90 \mathrm{~min}$. Plaques were counted with a $6 \cdot 5$ magnification.

\section{STATISTICAL ANALYSIS}

A comparison of the number of PFC for groups of mice was calculated by Student's $t$-test when the same variances were proven by the Fisher test. In the cases when variances were significantly different, a modification was used to calculate $t$ values. Since the number of PFC for groups of mice does not follow a normal distribution, ln values were also calculated and compared to the normal values.

\section{Results}

\section{CELL COUNTING MODIFICATION}

A modification was introduced in the cell counting method in an attempt to reduce the variances usually observed with this method. In the crystal violet solution, cell morphology is easily recognizable. In this manner, only cells presenting a round nucleus and little cytoplasm were counted assuming that this population would consist, primarily, of responder cells of the lymphocyte series. Consequently, by eliminating cells not directly involved in the cell cooperation response, variability in the drug, if any, should be more evident. Table 1 presents a comparison of the two counting methods, the conventional way and the one proposed by us. As can be observed, with this modification, the number of PFC is greater and more uniform, while the variance is greatly reduced. In view of these results, the modification was used to count cells in the following experiments.

\section{EFFECT OF CLOFAZIMINE ON SPLEEN CELLS}

The effect of clofazimine on the primary $\operatorname{IgM}-\mathrm{PFC}$ response was measured across a spectrum of 21 days. Two clofazimine concentrations were used since it has been 
Table 1. Cell-counting modification

\begin{tabular}{|c|c|c|c|c|c|}
\hline & $\mathrm{PFC} / 10^{6}$ & $\ln$ & & $\mathrm{PFC} / 10^{6}$ & $\ln$ \\
\hline \multirow{8}{*}{$\begin{array}{l}\text { Conventional } \\
\text { spleen } \\
\text { cell count }\end{array}$} & 1007 & $6 \cdot 915$ & \multirow{8}{*}{$\begin{array}{l}\text { Mononuclear } \\
\text { spleen } \\
\text { cell count }\end{array}$} & 1365 & $7 \cdot 219$ \\
\hline & 801 & $6 \cdot 686$ & & 1202 & $7 \cdot 092$ \\
\hline & 1027 & $6 \cdot 934$ & & 1180 & $7 \cdot 073$ \\
\hline & 1524 & $7 \cdot 329$ & & 1026 & 6.933 \\
\hline & 611 & $6 \cdot 415$ & & 1222 & $7 \cdot 108$ \\
\hline & 669 & $6 \cdot 506$ & & 1033 & $6 \cdot 940$ \\
\hline & 637 & $6 \cdot 457$ & & 1201 & $7 \cdot 090$ \\
\hline & 926 & $6 \cdot 831$ & & 1236 & $7 \cdot 120$ \\
\hline $\bar{X} \pm \mathrm{SD}$ & $900 \pm 300$ & $6 \cdot 759 \pm 0 \cdot 308$ & & $1183 \pm 110$ & $7 \cdot 072 \pm 0.094$ \\
\hline
\end{tabular}

Values given are the mean of triplicate plates for each mouse. Variances are significantly different for $P<0 \cdot 05$.

reported $^{9}$ that these concentrations, when given to mice inoculated with Mycobacterium leprae in the foot-pad, were effective in preventing bacterial multiplication. Mice were given the drug daily and groups of mice were killed at weekly intervals. Figure 1 gives the difference observed, in percentage, after 7, 14 and 21 days of treatment as compared to the control group receiving only sunflower oil. As can be seen PFC response is greatly increased at 14 days of treatment and begins to decrease after 21 days. The PFC response in clofazimine-

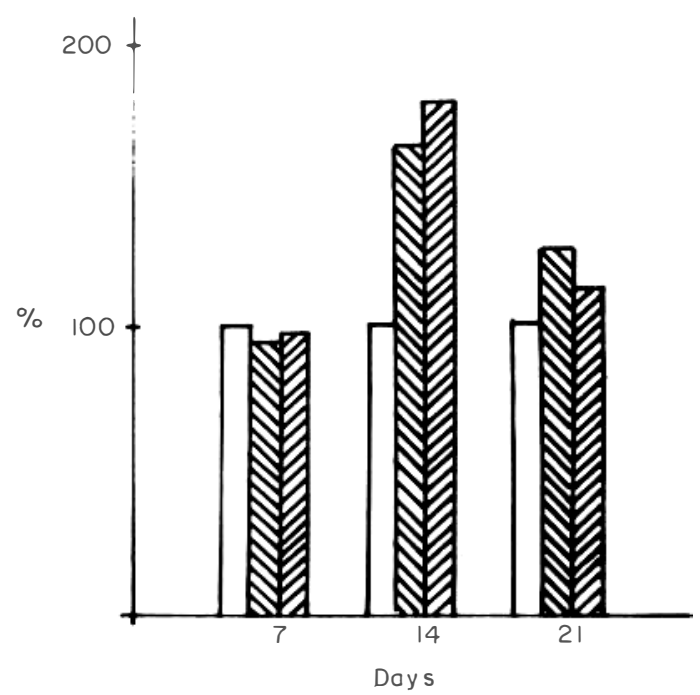

Figure 1. PFC increase in clofazimine-treated mice: $\square$, control group; $\mathbb{\$}, 1 \mathrm{mg} / \mathrm{kg}$ of body weight per day; $10 \mathrm{mg} / \mathrm{kg}$ of body weight per day. 
Table 2. Plaque-forming cell response in clofazimine-treated mice

\begin{tabular}{|c|c|c|c|c|c|c|}
\hline & & Day 7 & & Day 14 & & Day 21 \\
\hline Treatment & $n$ & $\bar{X} \pm \mathrm{SD}$ & $n$ & $\bar{X} \pm \mathrm{SD}$ & $n$ & $\bar{X} \pm \mathrm{SD}$ \\
\hline Untreated* & 8 & $\begin{array}{c}1183 \pm 110 \\
(7 \cdot 072 \pm 0 \cdot 102)\end{array}$ & 8 & $\begin{array}{c}1200 \pm 270 \\
(7 \cdot 069 \pm 0 \cdot 215)\end{array}$ & 7 & $\begin{array}{c}811 \pm 109 \\
(6 \cdot 688 \pm 0 \cdot 154)\end{array}$ \\
\hline Sunflower oil & 6 & $\begin{array}{c}1183 \pm 199 \\
(7 \cdot 063 \pm 0 \cdot 179)\end{array}$ & 8 & $\begin{array}{c}1170 \pm 330 \\
(7 \cdot 029 \pm 0 \cdot 290)\end{array}$ & 7 & $\begin{array}{c}796 \pm 67 \\
(6.677 \pm 0.084)\end{array}$ \\
\hline $\begin{array}{l}1 \mathrm{mg} / \mathrm{kg} \text { of body } \\
\text { weight per day }\end{array}$ & 6 & $\begin{array}{c}1106 \pm 127 \\
(7 \cdot 004 \pm 0 \cdot 115)\end{array}$ & 8 & $\begin{array}{c}1917 \pm 187 \dagger \\
(7 \cdot 554 \pm 0 \cdot 101) \ddagger\end{array}$ & 7 & $\begin{array}{c}1009 \pm 66_{\ddagger}^{+} \\
(6 \cdot 916 \pm 0 \cdot 064)_{+}^{+}\end{array}$ \\
\hline $\begin{array}{l}10 \mathrm{mg} / \mathrm{kg} \text { of body } \\
\text { weight per day }\end{array}$ & 6 & $\begin{array}{c}1136 \pm 191 \\
(7 \cdot 022 \pm 0 \cdot 178)\end{array}$ & 8 & $\begin{array}{c}2080 \pm 173 \dagger \\
(7 \cdot 070 \pm 0 \cdot 215) \ddagger\end{array}$ & 7 & $\begin{array}{c}897 \pm 52 \ddagger \\
(6 \cdot 798 \pm 0 \cdot 058) \ddagger\end{array}$ \\
\hline
\end{tabular}

* The values of the untreated mice were considered as those referring to the control group as well as the day 0 treatment. Numbers in parentheses are the $\ln$ transformed data.

$\dagger P<0.0005$ as compared to the sunflower oil control group.

$\ddagger P<0 \cdot 005$ as compared to the sunflower oil control group.

treated mice throughout 21 days of treatment can be observed in Table 2. Both concentrations of the drug increase after 14 days of drug treatment, although the $10 \mathrm{mg}$ concentration response is greater. By 21 days, the response is decreased, but both are higher than the control group and the $1 \mathrm{mg} / \mathrm{kg}$ of body weight per day has a higher response than the other drug concentration.

\section{Discussion}

The PFC response of mice receiving clofazimine at concentrations reported to prevent bacterial multiplication ${ }^{9}$ was significantly increased after 14 and 21 days of treatment with the drug. The response observed could be a collateral effect of macrophage function since studies carried out in our laboratories have shown that clofazimine exerts an action on macrophages not only in in vitro methods but also in in vivo systems within the same range of drug concentration. Several studies support the idea that macrophage presentation of immunogens to T-cells requires intracellular handling of the antigen. ${ }^{5}$ Then, after lysosomal digestion, antigen fragments would be transferred to accessible sites at the cell surface or released to the extracellular space where they may interact with I-region products and with specific T-cells. Since SRBC are a T-dependent antigen and are the antigen used in this model, the response would be due to an interaction between macrophages and T-lymphocytes. Also, there is ample evidence that monocytes can play a regulatory function in the proliferative response of lymphocytes to 
antigens ${ }^{10,11}$ and in the induction of antibody synthesis. ${ }^{11,12}$ Previous experiments with the trypanocidal drug, suramin, have shown that drug treatment of BCG-primed spleen cell cultures prevents the enhancement of anti-SRBC response to bacteria added to the cultures ${ }^{14}$. Suramin is known to accumulate in macrophages and interfere with the activity of lysosomal enzymes. ${ }^{13,14}$

If the reverse can be assumed to be true, then clofazimine which exerts its effect on macrophages, precisely in the lysosomal system, should enhance the anti-SRBC response in spleen cells. Nevertheless further research should be carried out to decipher the precise action of the drug on each immunocompetent cell population, i.e. the B-lymphocyte and the T-lymphocyte. Studies are being carried out in this laboratory to clarify the events which occur in the cellular cooperation mechanism.

\section{Acknowledgments}

The authors wish to thank Isabel Cristina Pérez for her excellent technical assistance, Dr Carlos García Santana for his helpful advice and Eslivia Préstamo for typing the manuscript. This investigation received support from the UNDP-World Bank WHO Special Programme for Research Training in Tropical Medicine.

\section{References}

1 Research in Leprosy. A report of a committee set up by the medical council to study future prospects. Clin exp Imm, 1979; 36: 1.

2 Sarracent J, Finlay CM. The action of clofazimine on the level of lysosomal enzymes of cultured macrophages. Clin exp Imm, 1982; 48: 261.

3 Sarracent J, Finlay CM. Phagocytosis and intracellular degradation of I ${ }^{125}$-labelled immune complexes by clofazimine treatment of macrophage cultures. Clin exp Imm, 1982; 48: 268.

${ }^{4}$ Zeigler HK, Unanue ER. Decrease in macrophage antigen catabolism caused by ammonia and chloroquine is associated with inhibition of antigen presentation to T cells. Proc Natl Acad Sci USA, 1982; 79: 175.

${ }^{5}$ Miller JFAP, Mitchell GR. Cell to cell interaction in the immune response. I. Hemolysinforming cells in neonatally thymectomized mice reconstituted with thymus or thoracic duct lymphocytes. $J \operatorname{exp~Med,1968;128:~} 801$.

${ }^{6}$ Mitchell GF, Miller JFAP. Cell to cell interaction in the immune response. II. The source of hemolysin-forming cells in irradiated mice given bone-marrow and thymus or thoracic duct lymphocytes. $J$ exp Med, 1968; 128: 821 .

7 Maillard J, Bloom BR. Immunological adjuvants and the mechanism of cell cooperation. $J$ exp Med, 1972; 186: 285.

8 Cunningham AJ, Szenberg A. Futher improvements in the plaque technique for detecting single antibody forming cells. Immunology, 1968; 14: 599.

9 Sheppard CC, Chang YT. Activity of antituberculosis drugs against Mycobacterium leprae. Studies with experimental infection of mouse foot pads. Int J Lepr, 1964; 32: 196. 
10 McCombs C, Michalski JP, Talal N. Cellular interactions in lymphocyte proliferation: effect of syngeneic and xenogeneic macrophages. Cellular Immunol, 1976; 23: 283.

"Johansson A, Hefors E, Biberfeld R. An electron microscopic study of the contacts between human peripheral T-lymphocytes and autologous monocytes in culture. J Submicr Cytol, 1978; 10: 281.

12 Rosenthal AS, Shevach EM. The function of macrophages in T-lymphocyte antigen recognition. Contemp Top Immunol, 1976; 5: 47.

13 Buys Ch CM, Elferink Marieka GL, Bouma JMW, Gruber M, Nieuwenhuis P. Proteolysis of formaldehyde-treated albumin in Kupffer cells and its inhibition by suramin. $J$ Reticuloendothel Soc, 1973; 14: 209.

${ }^{14}$ Pesanti GL. Suramin effects on macrophage phagolysosome formation and antimicrobial activity. Infect Immun, 1978; 20: 503. 